Government that it can not for a moment entertain, much less discuss, a suggestion that respect by German naval authorities for the rights of citizens of the United States upon the high seas should in any way or in the slightest degree be made contingent upon the conduct of any other Government affecting the rights of neutrals and noncombatants. Responsibility in such matters is single, not joint; absolute, not relative."

So far, therefore, as the correspondence is concerned, the attitude of both Governments remains essentially unchanged, and none of the questions involved has received a final solution.

David Jayne Hill:

\title{
BRITISH ORDERS IN COUNCIL AND INTERNATIONAL LAW
}

From time to time the press informs the public that on such and such a date a British Order in Council has been issued affecting the rights of neutrals, and the question is debated whether or not the Order in Council, contrary to international law, is binding upon neutrals and whether, indeed, the Order contrary to international law is binding upon prize courts in which the question of capture of neutral property is to be contested. It is therefore of interest to consider the nature of an Order in Council, its relation to an act of Parliament, its effect upon the rights of neutrals, and its authority in British prize courts.

Sir William Anson says, in The Law and Custom of the Constitution, that "an Order in Council is practically a resolution passed by the King in Council, communicated by publication or otherwise to those whom it may concern." After this brief definition, the learned author gives the following as an example of the wording of such an order:

At the Court at , the 1st day of June, 1907.

\section{Present, -}

The King's most excellent Majesty in Council.

His Majesty, by and with the advice of his Privy Council, doth order and it is hereby ordered.

After contrasting the Cabinet and Privy Council, of which latter body the Cabinet are members, the same learned author says:

The Cabinet considers and determines how the King's Government may best be carried on in all its important departments; the Privy Council meets to carry into

${ }^{1}$ Anson's Law and Custom of the Constitution, Vol. II, 3d ed., Part 1, p. 50. 
effect advice given to the King by the Cabinet or by a Minister, or to discharge duties cast upon it by custom or statute.

He concludes this part of the subject with the statement that "the Privy Council is essentially an executive, the Cabinet a deliberative body. The policy settled in the Cabinet is carried out by Orders in Council, or by action taken in the various departments of government.",2

If, as Sir William Anson says, the Privy Council is essentially an executive body, it follows that the King in Council issues orders of an executive nature. He may do so in each of two cases, the first of which is in accordance with custom and to give effect to the prerogatives of the Crown; the second is in pursuance of an act of Parliament, vesting the King in Council with authority to do a specific act. In the first case the jurisdiction of the King in Council is limited, as it could not be successfully claimed to-day that the King in Council, even though the members of the Cabinet be present and should so advise, could legislate, as Parliament is the legislative body of Great Britain. In the second case, the King in Council acts pursuant to parliamentary and statutory authority, and to the extent of the statutory authority the Orders have the force of law.

They are, however, only in form Orders in Council; in fact they are acts of Parliament, as they are authorized by Parliament and therefore, if within the statute, are equivalent to a statute. Mr. Jenks, in his Short History of English Law, thus states the reason and the effect of the Order in Council made in pursuance of an act of Parliament:

Owing partly to the necessity for leaving the application of discretionary legislation to the Executive, but still more to the impossibility of discussing details in an overworked Parliament, it has become increasingly common for Parliament to delegate, cither to the Crown (i.e., the Executive as a whole) or even to the Minister at the head of the department charged with carrying out the Act, the power of making Rules or Orders under it. These Rules and Orders are, in effect, so long as they keep within the authority prescribed by their respective Acts, themselves Parliamentary statutes, and are enforced by the Courts as such. I $i$ is, of course, in theory, possible to raise against any of them the plea of ultra vires; but they are usually drawn with sufficient skill to render such an attack hopeless. $* * *$ The difference between Orders made by the Crown in Council and those made by a single Minister, is more apparent than real. For, in the former case, as in the latter, the form and

2 Anson's Law and Custom of the Constitution, Vol. II, Part 1, p. 98. 
contents are virtually settled by the departments concerned; the approval by the Privy Council is a pure formality. ${ }^{3}$

But whether the Order in Council be in virtue of a custom or of the King's prerogative-which cannot, however, be contrary to a statute of Parliament-or whether it be in pursuance of parliamentary authority and is thus to be considered as an aet of Parliament, it would seem to be too clear for argument that an Order in Council, if it be considered a statute, is municipal; that if it be legislative it is domestic legislation, and while it may affect persons within British jurisdiction it cannot properly be extended, any more than a statute can properly be extended, beyond the jurisdiction of Great Britain so as to affect the rights of foreign countries, their subjects or citizens.

For this statement, it does not seem necessary to oite authority, and yet, in view of the fact that Orders in Council have been issued during the wars of the French Revolution and the Empire which seriously affected the rights of neutrals beyond British jurisdiction, and in view of the further fact that some of the Orders in Council issued since the outbreak of the great war affect neutral rights, it seems advisable to quote an authority distinctly negativing the claim of any country to legislate for other than its own subjects or citizens, which claim, if allowed, would violate the perfect equality of states upon which the society of nations is predicated and without which it could not exist. In the case of The Antelope (10 Wheaton 66, 122), decided in 1825, Chief Justice Marshall, speaking for the Supreme Court of the United States, said:

No principle of general law is more universally acknowledged, than the perfect equality of nations. Russia and Geneva have equal rights. It results from this equality, that no one can rightfully impose a rule on another. Each legislates for itself, but its legislation can operate on itself alone.

A few years before, Sir William Scott so held in the case of The Louis (2 Dodson, pp. 210, 243-44), which it is important to quote in this connection in order that it may appear clear, beyond the possibility of misconception, that the courts of Great Britain as well as the courts of the United States recognize the equality and independence of states and the right of states as such freely to navigate the ocean without let or hindrance by legal statute, whether that statute be termed an Order

${ }^{3}$ Jenks, A Short History of English Law, 1912, p. 188. 
in Council or an act of Parliament. In the case of The Louis, decided in 1817 , that great and learned judge said:

Two principles of public law are generally recognized as fundamental. One is the perfect equality and entire independence of all distinct states. Relative magnitude creates no distinction of right; relative imbecility, whether permanent or casual, gives no additional right to the more powerful neighbor; and any advantage seized upon that ground is mere usurpation. This is the great foundation of public law, which it mainly concerns the peace of mankind, both in their politic and private capacities, to preserve inviolate. The second is, that all nations being equal, all have an equal right to the uninterrupted use of the unappropriated parts of the ocean for their navigation. In places where no local authority exists, where the subjects of all states meet upon a footing of entire equality and independence, no one state, or any of its subjects, has a right to assume or exercise authority over the subjects of another.

It would seem to follow from these decisions that an act of Congress or a British statute inconsistent with international law is null and void in so far as foreign nations are concerned and in so far as their citizens and subjects not within the jurisdiction of the United States or of Great Britain are concerned, although it may well be, and is in fact the case, that an act of Congress or an act of Parliament contrary to international law binds the authorities of the United States and American citizens, on the one hand, and British authorities and British subjects, on the other.

Finally, the question arises as to the effect of an Order in Council upon British prize courts, a question to be determined exclusively by Great Britain, which can by statute prescribe the law to be administered in British prize courts. To the foreigner it is immaterial whether the law is prescribed by an act of Parliament or by an Order in Council, as the question is not what particular municipal organ may prescribe the law but whether the law has been prescribed in such a way as to force the prize court to apply a rule contrary to international law in the decision of cases involving neutral rights. Whether this be done by act of Parliament or by Order in Council is a matter of indifference to the foreign nation, whose desire is that it be done neither by one nor the other, nor both working in common. It is, of course, a matter of cansiderable importance to British authorities in the performance of their duties whether they are or are not bound by an Order in Council, but this is a question of constitutional, and therefore domestic, not of international, law. 
The nature of an Order in Council and its effect upon a British prize court was recently considered in the case of the Zamora, ${ }^{4}$ and the holding of the Judicial Committee of the Privy Council on appeal has been a source of much favorable comment on the part of American publicists. It is believed, however, that, carefully considered, the decision, while worthy of the greatest respect, is not to be taken as laying down the broad principle that a British prize court cannot decide a case involving neutrals against international law; but that the statute creating the prize court and prescribing that its decisions be in accordance with the law of nations cannot be varied by an order of the King in Council, although it may be varied by an act of Parliament.

Briefly stated, the facts in the case were that the Zamora, a Swedish (therefore a neutral) ship, bound from New York to Stockholm (therefore on a voyage between two neutral points), was seized off the coast: of Scotland, between the Faroe and Shetland Islands, on April 8, 1915, by a British cruiser, and sent into the Orkney Islands as prize. The vessel carried copper and, during proceedings instituted in the prize court for the condemnation of the ship and cargo because of the contraband character of the latter, "the Crown applied to the prize court for an interlocutory order that about 400 tons of copper, which formed part of the cargo, should be released and delivered up to the Crown under Order XXIX of the Prize Court Rules, upon an undertaking of the Crown to pay into court the appraised value of the copper in accordance with Rule 5 of the Order." This request was based upon the Prize Court Rules issued by the King in Council, allowing cargo to be requisitioned by the Crown pending the decision of the court upon the validity of the capture. The application was resisted on behalf of the Swedish firm which claimed to own the cargo on the ground "that the provisions of the Order referred to violated the law of nations and were not binding upon the court."

Sir Samuel Evans, President of the Prize Court, decided that the Order in Council was imperative in nature, that is, that it commanded him to grant the application of the Crown made in pursuance of the Order, and decreed as requested.

Upon appeal to the Judicial Committee of the Privy Council, that ${ }^{4}$ Printed in this Journal for April, 1916, p. 422. 
learned body reversed the decision of the prize court, not because the Crown did not possess the right to requisition the copper, but because, in the opinion of their lordships, no sufficient evidence had been adduced by the Crown for the necessity of such requisition. In the course of its decision the Privy Council stated that the Order in Council invoked in the case was not imperative, as Sir Samuel Evans had supposed, and that even if it were imperative it would not be binding upon the court if inconsistent with the law of nations, because by statute the British prize court is required and authorized, as their lordships said, "to proceed upon all and all manner of captures, seizures, prizes, and reprisals of all ships or goods that are or shall be taken, and to hear and determine according to the course of admiralty and the law of nations." Their lordships stated, in clear and unmistakable terms, per Lord Parker, who delivered their judgment, that an Order of the King in Council contrary to international law did not bind the prize court, for the very simple reason that the prize court was constituted "to hear and determine according to $* * *$ the law of nations" and that an Order in Council could not modify the law of nations.

The court, however, did not say that Parliament could not prescribe a rule of decision contrary to the law of nations. Indeed, the judgment expressly declared that Parliament possessed this power and that a British prize court was bound to obey and give effect to an act of Parliament, even although such act should be contrary to the law of nations. The King in Council could prescribe procedure to be observed in the prize court not inconsistent with the law of nations. Parliament could not merely prescribe procedure at variance with the law of nations but could pass a statute in the teeth of international law.

It should further be said that their lordships did not deny the right under international law to requisition vessels or goods before their condemnation, but expressly affirmed this right and reversed the judgment of the prize court, because in the exercise of this right the judge, Sir Samuel Evans, had not had evidence before him which would justify the requisition. It is perhaps well to quote this portion of the judgment before proceeding to that portion dealing with the Order in Council.

On the whole question their lordships have come to the following conclusion: $A$ belligerent Power has by international law the right to requisition vessels or goods 
in the custody of its prize court pending a decision of the question whether they should be condemned or released, but such right is subject to certain limitations. First, the vessel or goods in question must be urgently required for use in connection with the defence of the realm, the prosecution of the war, or other matters involving national security. Secondly, there must be a real question to be tried, so that it would be improper to order an immediate release. And, thirdly, the right must be enforced by application to the prize court, which must determine judicially whether, under the particular circumstances of the case, the right is exercisable.

In speaking of the effect of the Order in Council in a court of prize and of the nature of the prize court itself, Lord Parker said, speaking for the court:

In the first place, all those matters on which the court was authorized to proceed were, or arose out of, acts done by the sovereign power in right of war. It followed that the King must, directly or indirectly, be a party to all proceedings in a court of prize. In such a court his position was in fact the same as in the ordinary courts of the realm on a petition of right which had been duly fiated. Rights based on sovereignty were waived and the Crown accepted for most purposes the position of an ordinary litigant. A prize court must, of course, deal judicially with all questions which came before it for determination, and it would be impossible for it to act judicially if it were bound to take its orders from one of the parties to the proceedings.

In the second place, the law which the prize court was to administer was not the national, or, as it was sometimes called, the municipal law, but the law of nationsin other words, international law. It was worth while dwelling for a moment on that distinction. Of course, the prize court was a municipal court and its decrees and orders owed their validity to municipal law. The law which it enforced might, therefore, in one sense, be considered a branch of municipal law. Nevertheless, the distinction between municipal and international law was well defined. A court which administered municipal law was bound by and gave effect to the law as laid down by the sovereign state which called it into being. It need inquire only what that law was, but a court which administered international law must ascertain and give effect to a law which was not laid down by any particular state, but originated in the practice and usage long observed by civilized nations in their relations with each other or in express international agreement.

It was obvious that, if and so far as a court of prize in this country was bound by and gave effect to orders of the King in Council purporting to prescribe or alter the international law, it was administering not international but municipal law; for an exercise of the prerogative could not impose legal obligation on anyone outside the King's dominions who was not the King's subject. If an Order in Council were binding on the prize court such court might be compelled to act contrary to the express terms of the commission from which it derived its jurisdiction.

There was yet another consideration which pointed to the same conclusion. The acts of a belligerent Power in right of war were not justiciable in its own courts unless such Power, as a matter of grace, submitted to their jurisdiction. Still less were such acts justiciable in the courts of any other Power. As was said by Mr. Justice 
Story in the case of The Invincible (2 Gall., 43), "acts done under the authority of one sovereign can never be subject to the revision of the tribunals of another sovereign, and the parties to such acts are not responsible therefor in their individual capacity." It followed that, but for the existence of courts of prize, no one aggrieved by the acts of a belligerent Power in times of war could obtain redress otherwise than through diplomatic channels and at the risk of disturbing international amity. An appropriate remedy was, however, provided by the fact that, according to international law, every belligerent Power must appoint and submit to the jurisdiction of a prize court, to which any person aggrieved had access, and which administered international as opposed to municipal law-a law which was theoretically the same, whether the court which administered it was constituted under the municipal law of the belligerent Power or of the sovereign of the person aggrieved, and was equally binding on both parties to the litigation. It had long been well settled by diplomatic usage that in view of the remedy thus afforded, a neutral aggrieved by any act of a belligerent Power cognizable in a court of prize ought, before resorting to diplomatic intervention, to exhaust his remedies in the prize courts of the belligerent Power.

A case for such intervention arose only if the decisions of those courts were such as to amount to a gross miscarriage of justice. It was obvious, however, that the reason for that rule of diplomacy would entirely vanish if a court of prize, while nominally administering a law of international obligation, were in reality acting under the direction of the Executive of the belligerent Power.

His lordship, however, made it perfectly clear that the power resided in Parliament to pass an act contrary to international law and that in such a case it would be the duty of the judges of the prize court, as British judges, to obey and to apply the statute.

It could not, of course [he said], be disputed that a prize court, like any other court, was bound by the legislative enactments of its own sovereign state. A British prize court would certainly be bound by acts of the Imperial Legislature. But it was none the less true that if the Imperial Legislature passed an act the provisions of which were inconsistent with the law of nations, the prize court in giving effect to such provisions would no longer be administering international law. It would in the field covered by such provisions be deprived of its proper function as a prize court. Even if the provisions of the act were merely declaratory of the international law, the authority of the court as an interpreter of the law of nations would be thereby materially weakened, for no one could say whether its decision were based on a due consideration of international obligations or on the binding nature of the act itself. The fact, however, that the prize courts in this country would be bound by acts of the Imperial Legislature afforded no ground for arguing that they were bound by the Executive Orders of the King in Council.

It would be easy to quote passages from British and American decisions that prize courts are courts of international law sitting in belligerent countries, that in the performance of their duties they administer 
and are bound to administer the law of nations and to reject provisions of their municipal laws contrary to the law of nations. In this connection, The Maria (1 C. Rob., 340), The Recovery (6 C. Rob. 341), and The Fox (Edw. 312), all of which were decided by Lord Stowell, are frequently referred to, for the proposition that a prize court is an international court, bound to administer the law of nations.

On the other hand, decisions of American prize courts are not want ing to the effect that, international in theory, prize courts are in fact municipal. Thus, in the case of the Amy Warwick (2 Sprague 123), it was said:

Prize courts are subject to the instructions of their own sovereign. In the absence of such instructions their jurisdiction and rules of decision are to be ascertained by reference to the known powers of such tribunals and the principles by which they are governed under the public law and the practice of nations. ${ }^{5}$

There can be no doubt that a court in which the rights of various nations, their subjeets or citizens are determined should act in accordance with that law common to the parties, not by that law prescribed by one of them. In other words that international, not municipal, law should be administered. But it is believed that nothing is gained by claiming that prize courts are international courts when in fact they are municipal in location and composed of judges of the country in which they are situated, bound by their oath to obey the laws of their land. The proper thing to do is to create an international court of prize, as was recommended by the Second Hague Conference, to operate at The Hague and to be composed of judges of different nations, sworn to administer the law of nations, not the law of any one of them. Then will the views of Sir James Mackintosh, laid down by him in the case of The Minerva, be a statement of fact rather than a generous aspiration:

Undoubtedly the letter of the instructions was a sufficient warrant for His Majesty's officers for detaining ships which appeared to offend against it; but as to the doctrine that courts of prize were bound by illegal instructions, he had already in a former case (that of the Erin), treated it as a groundless charge by an American writer against English courts. In this case (which had hitherto been, and he trusted ever would continue, imaginary) of such illegal instructions, he was convinced that English courts of admiralty would as much assert their independence of arbitrary mandates as English courts of common law. That happily no judge had ever been called upon to de-

${ }^{5}$ Quoted from Moore's Int. Law Dig., Vol. VII, p. 600. 
termine, and no writer had distinctly put the case of such a repugnance. He had, therefore, no direct and positive authority; but he never could hesitate in asserting, that in such an imaginary case, it would be the duty of a judge to disregard the instructions, and to consult only that universal law to which all civilised princes and states acknowledge themselves to be subject, and over which none of them can claim any authority. ${ }^{6}$

JAMES BRown ScotT.

\section{THE INTERNATIONAL HIGH COMMISSION ON UNIFORMITY OF LAWS}

The first general meeting at Buenos Aires, April 3-12, 1916, of the International High Commission on Uniformity of Laws created by the First Pan American Financial Conference was an event of supreme significance. Its great possibilities of service in laying the foundations for an effective international organization of the Republics of the Western Hemisphere make a striking appeal to the imagination.

The First Pan American Financial Conference was held in Washington May 24-29, 1915, in response to the invitation of the United States Government. All the American Republics were represented, except Mexico and Haiti. Its purpose was well set forth by the Honorable W. G. McAdoo, Secretary of the Treasury, in the following words:

The outbreak of the European War accentuated many of our problems, and brought clearly home to the American Republics the danger of complete dependence upon the great European states for their economic development and commercial security. All of them, including the United States, face at the beginning of the war the possibilities of appalling disaster. That experience clearly shows the imperative necessity for closer relations between the American states themselves and a more enduring organization of their own life in order that they may work out their destinies, freed as far as possible from the dangers which constantly menace their economic development through European complications. It was essential in these ircumstances that the American nations should take measures for their own protection; that they should reconstruct, as far as practicable, their commercial and financial relationships for the security of their own interests and the welfare of their people.

The discussions of this conference centered about three main topics: (1) The granting by United States bankers and business men of ample credits to Latin America and the provision of the necessary organization and facilities for this purpose; (2) The prompt establishment of adequate

'Life of the Right Honourable Sir James Mackintosh, Vol. I, pp. 317-319; Phillimore's Int. Law, Vol. III, p. 656. 